American Journal of Applied Sciences 7 (3): 331-342, 2010

ISSN 1546-9239

(C) 2010Science Publications

\title{
Extraction of Protein from Common Plant Leaves for Use as Human Food
}

\author{
A.E. Ghaly and F.N. Alkoaik \\ Department of Agricultural Engineering, College of Food Science and Agriculture, \\ King Saud University, Riyadh, Kingdom of Saudi Arabia
}

\begin{abstract}
Problem statement: Protein deficiency is one of the major nutritional problems in the developing world. The most disastrous consequences occur in children where protein malnutrition manifests itself in forms of two notorious diseases: Marasmus and kwashiorkor. Expansion of present agricultural practices into marginal lands is expected to solve this chronic protein shortage. The process of photosynthesis is the only non depletable protein source and can supply some essential amino acids as well as provide adequate nitrogen in the diet for synthesis of non essential amino acids in addition to vitamins and minerals. Approach: The aim of this study was to assess the nutritional values of common plant leaves and determine the feasibility of using them as a protein supplement. Six plants were cultivated and tested for their nutritional quality: amaranth, cowpea, sugar been, pumpkin, sweet potato and cabbage. Results: Pumpkin leaves recorded the highest protein yield $(11.75 \%)$ followed by amaranth (10.5\%) The protein contents in the leaves of sweet potato, cowpea, cabbage and sugar been were much lower (7.85, 6.95, 5.60 and 3.45\%, respectively). Conclusion: Except for sugar bean, all plants had higher extractable protein content than cabbage. Proper use of the growing season can achieve high protein yield. Clean cutting will ensure that the leaves do not deteriorate within a few hours when kept in cool place and freezing leaves can improve protein extractability. The test plants should be given a trial as protein sources for human. Plant leaves have vitamins, minerals and essential amino acids and when consumed in adequate amounts they can supplement protein especially in areas where the environment is very hostile to livestock keeping or where fish protein is lacking. The optimum harvest age, fertilizer requirements and the possibility of combining two or more plants together to improve protein content should be studied. The amino acid, minerals and vitamins profiles should also be determined.
\end{abstract}

Key words: Protein, leaves, malnutrition, extraction, masamus, kwashiorkor

\section{INTRODUCTION}

The world is coming to recognize the grim truth that ultimately the population growth will outstrip food suppliers with apocalyptic results. About 36 million people die every year due to hunger or as a result of hunger (Gasperini and Maguire, 2001). Approximately, $60 \%$ of the 10.9 million deaths each year among children under the age of five in the developing world are attributed to malnutrition (WHO, 2002a). If the current average birth rate continues, the world's population will grow from the current 6.7-9.2 billion by the year 2050, most of which will be in the less developed countries, the countries least able to feed their children (WHO/UN, 2007). Feeding 9.2 billion people at the current dietary levels presents the staggering necessity of increasing the earth's food producing capacity to a rate never seen before. Protein deficiency is one of the major nutritional problems in the developing world (Latharn, 1997). The development of novel protein sources such as Fish Protein Concentrate (FPC) (Pariser et al., 1978; Sikka et al., 1979), Single Cell Protein (SCP) (Tannenhaum and Wang, 1975; Ferrianti and Fiechter, 1983) and Soybean Protein (SBP) (Mendez et al., 2002; Bhatia and Greer, 2008) have made significant contributions toward the alleviation of the world protein deficiency (Kuijer and Wielenga, 1999). However, there is still an estimated one billion people suffering from protein deficiency and malnutrition. Therefore, new methods of feeding the underfed world population, especially in the less developed countries, have to be developed. Those methods that will guarantee a continuous protein supply require most serious attention since most malnutrition cases have

Corresponding Author: A.E. Ghaly, Department of Agricultural Engineering, College of Food Science and Agriculture, King Saud University, Riyadh, Kingdom of Saudi Arabia 
been found to be a result of protein insufficiency. There is agreement among scientists that protein malnutrition contributes to the high death rate among infants and children of the less developed countries and causes among the survivors debilitating weakness, higher susceptibility to disease and irreversible brain damage (FAO, 2008; WHO, 2002b).

In most under developed countries, the majority of the people are vegetarian and even where it is possible to obtain meat the price is too high that most families do not have meat more than once a week. Therefore, expansion of present agricultural practices into marginal lands is expected to solve this chronic world food shortage. The process of photosynthesis is the only non depletable protein source and can supply some essential amino acids as well as provide adequate nitrogen in the diet for synthesis of non essential amino acids (Kinsella, 1970; Staman, 1970). However, only a very small percentage of the world edible plants are being utilized for human food. Furthermore, about $90 \%$ of the world plant food comes from only 20 crops and in many countries only 6 crops are actually exported/imported (Parrish et al., 1974). Leafy vegetable protein is about half the vegetable protein content in the human diet and probably contributes more to the world protein total than do fish, although less attention is given to it.

Two factors limit the nutritional value of plant leaves to monogastric animals: The high fiber content and the indigestibility of cellulose (Kinsella, 1970). Normally animals assimilate the plant protein and they are In turn are consumed by human and through this food chain man avoid the cellulose. However, this food chain system is very inefficient in under developed countries since most people do not eat enough animal protein for economic reasons. Moreover, only $8-20 \%$ of the plant protein consumed by animals is recoverable as protein for hum nutrition. Thus, more efficient ways of utilizing plant protein must be found. The aim of this study was to assess the nutritional values of common plant leaves and determine the feasibility of using them as a protein supplement.

\section{Literature review:}

Proteins: Proteins are vital body nutrients, just as fats and carbohydrates, vitamins and minerals. However, proteins, together with dietary fats, are required by the body in larger amounts than vitamins and minerals because they are the primarily body building block sources for new tissue (Kinsella, 1970). Proteins are essential to all bioprocesses and are converted into specialized body proteins in various parts of the body including: the blood, muscles, enzymes, hormones, skin and hair. Haemoglobin in red blood cells, antibodies in blood plasma, insulin and hormones are all proteins or composed primarily of protein. All enzymes, the biological catalysts which make possible the myriad of bioprocesses, are proteins. Examples are: (a) the digestive enzymes which are used to break down complex organic compounds into simpler ones for easy absorption in the body, (b) the enzymes of respiration which permit energy transfer from metabolic processes into muscle action, energy for synthesis of new matter, heat energy and many other living functions and (c) the enzymes of the protoplasts in plant leaves which harness the energy from the sun in a complex process called photosynthesis (Badaloo et al., 2006). The main tissue protein assembling units are the essential amino acids which come only from the protein in foods. Thus, if protein supply is cut short, synthesis of body protein is impaired and may finally ceases (Williams, 1953).

Proteins are important class of biological macromolecules found in all organisms. They are mad from elements such as carbon, hydrogen, oxygen, nitrogen and sulphur. Based on their size (1-100 nm), proteins are nanoparticles (Paulin et al., 1951). All proteins are polymers of amino acids. The polymers (known as polypeptides) consist of sequences of 20 different $\mathrm{L}-\alpha$-amino acids (referred to as residues). For chains under 40 residues, the term peptidesis frequently used instead of proteins. To be able to perform their biological functions, proteins must possess at least 50 residues. The current estimate for the average protein length is 300 residues (Brocchieri and Karlin, 2005). There are 4 distinct aspects of protein structures: Primary, secondary, tertiary and quaternary (Fig. 1).

Amino acids: Amino acids are molecules containing an amino group, a carboxyl acid group and a side chain that varies between different amino groups. Alphaamino acid (Fig. 1) has the general formula $\mathrm{H}_{2} \mathrm{CHRCOO}$ where $\mathrm{R}$ is an organic substituent. Amino acids are critical to life and have many functions in metabolism. They are the building blocks of proteins and every protein is defined by its unique sequence of amino acid residues. Amino acids are linked together in varying sequences to form a vast variety (several hundred thousands) of proteins (Paulin et al., 1951; Chaing et al., 2007).

There are 20 amino acids useful to humans, some of which are essential (Table 1). An essential amino acid is one that cannot be synthesized by the organism and must, therefore, be supplied in the diet. Eight amino acids are essentials: Isoleucine, lysine, methionine, phenylalanine, threonine, tryptophan, valine and lucine (Young, 1994). Cysteine (sulphur containing amino acid), tyrosine (aromatic amino acid), histidine and arginine are required by infants and growing children (Imura and Okada, 1998; WHO, 2007). 
Am. J. Applied Sci., 7 (3): 331-342, 2010

Table 1: Essential and nonessential amino acids (Furst and Stehle, 2004; Reeds, 2000)

\begin{tabular}{ll}
\hline Essential amino acids & Nonessential amino acid \\
\hline Isoleucine* & Alanine \\
Arginine & Aspartate \\
Lysine & Cysteine* \\
Methionine & Glutamate \\
Phenylalanine & Glutamine* \\
Threonine & Glycine* \\
Tyrosine* & Proline* \\
Tryptophan & Serine* \\
Histidine* & Asparagine* \\
Valine & Selenocysteine* \\
Lucine & \\
\hline *: Essential in certain cases, normally not required in diet but some \\
people do not synthesize them
\end{tabular}<smiles>[R]C(N[TlH])C(=O)O</smiles>

(a)

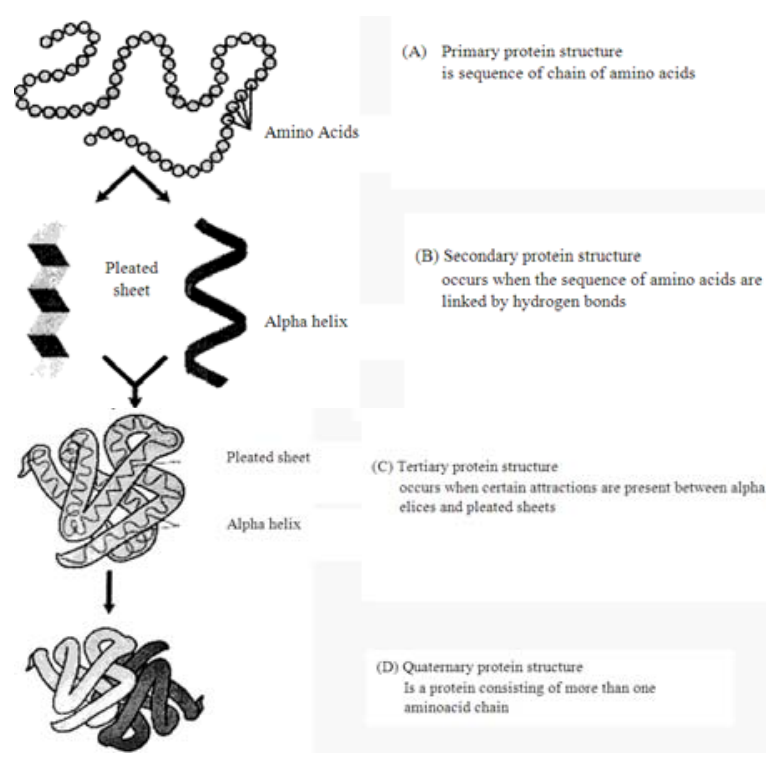

(b)

Fig. 1: Structures of amino acid and proteins (a) L- $\alpha-$ amino acid and (b) Protein

The amino acids arginine, cyteine, glycine, glutamine, histidine, proline, serine and tyrosine are considered (conditionally essential, meaning that they are not normally required in the diet but must be supplied exogenously to specific populations that do not synthesize them (Furst and Stehle, 2004).
Table 2: Recommended daily amount of amino acids (WHO, 2007)

\begin{tabular}{lc}
\hline Amino acid & $\mathrm{mg} \mathrm{kg}^{-1}$ body weight \\
\hline Isoleueine & 20 \\
Lysine & 39 \\
Methionine & 11 \\
Cysteine & 4 \\
Phenylalanine & 15 \\
Tyrosine & 10 \\
Threonine & 15 \\
Tryptophan & 4 \\
Valine & 15
\end{tabular}

Note: The recommended daily intake for children under 3 years is 10 times higher than the adults recommended daily amount. The recommended daily intake for infants (less than 1 year old) can be as high as 150 times the adult recommended daily amount

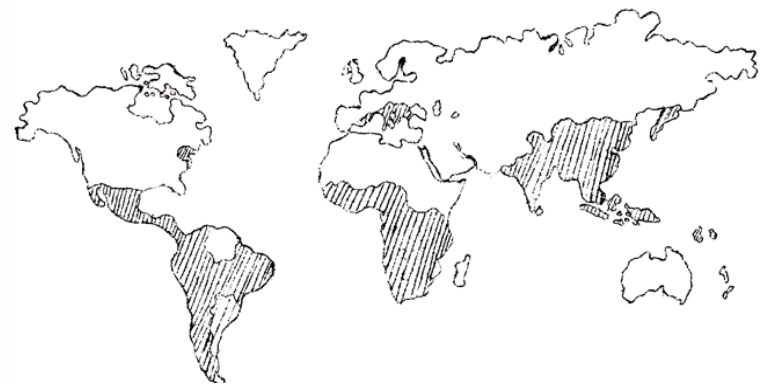

Fig. 2: Global geographical distribution of malnutrition

Food stuffs that lack essential amino acids are poor sources of protein equivalents as the body tends to deaminate the amino acids obtained, converting them stuffs that lack essential amino acids are poor sources of protein equivalents as the body tends to deaminate the amino acids obtained, converting them into fats and carbohydrates (McGilvery, 1979). Therefore, a balance of essential amino acids is necessary for a high degree of net protein utilization (defined as the mass ratio of amino acids converted: Protein: Amino acids supplied). Animal sources of proteins such as meat, poultry, egg, fish, milk and cheese provide all essential amino acids. Near complete protein can be found in some plant sources such as buckwheat, henseed and amaranth (CDCP, 2008; JADA, 2003). The recommended daily amounts of amino acids are shown in Table 2.

Distribution and availability of protein: Although protein is costly to produce, it is the greatest limitation to growth and good health (Altschul, 1965). There is a great disparity in protein usage by the various nations. Figure 2 shows the global geographical distribution of malnutrition. The total eaten protein in the Middle East is about $50 \mathrm{~g}$ of protein per day, of which $39 \mathrm{~g} \mathrm{(78 \% )}$ are of vegetable origin whereas in North America and Europe the total eaten protein is about $95 \mathrm{~g}$ of protein per day, of which $42 \mathrm{~g}(43 \%)$ are of vegetable origin 
(Kinsella, 1970). As the world population increases the problem will become more acute and will spread to larger areas. The low protein content in the diet is associated with the low level of animal protein supply and results in acute clinical symptoms, particularly among children. Moreover, even when children survive the aftermath leaves its mark on adulthood and renders the adults more susceptible to further debilitations when exposed to diseases which normally would be tolerated by people with a history of good nourishment.

Therefore, protein deficiency requires special attention for the following reasons: (a) the scientific evidence available now points to the fact that a part from calorie shortage, protein deficiency diseases are the major cause of malnutrition in low income countries, (b) protein deficiencies present special difficulties because of inadequate methods of diagnosis, (c) protein deficiencies in under developed countries are always linked with other deficiencies so that accurate clinical diagnosis and epidemiological studies may be difficult, (d) proteins are complex chemical compounds and there are wide variations in their composition based on their sources, storage, processing and cooking, (e) proteins are required in considerable amounts each day and deficiency cannot (except possibly as an emergency measure) be dealt with through provision of medicine and (f) proteins are normally among the most expensive foods and their immediate provision in many countries may entail imports which could be difficult based on general financial grounds in poor countries (Kinsella, 1970).

Protein malnutrition: It is not enough to present statistics which indicate that protein supplies are inadequate for large population groups. It is, thus, necessary to demonstrate that malnutrition actually occurs as a clinically identifiable disease. The most disastrous consequences occur in children where protein malnutrition manifests itself in forms of two notorious diseases: Marasmus and kwashiorkor.

Kwashiorkor is a case of severe protein deficiency with the absence of serious calorie deficiency. It is a medical name for malnutrition when a child is weaned and the diet that replaces beast milk is high in carbohydrates and deficient in protein as is common in many parts of the world where the bulk of the diet is made of starchy vegetables (Williams, 1953). The name is derived from one of the languages in coastal Ghana, translated "first-second". It means the rejected one, reflecting the development of the condition in the older child after the second one is born. A picture of a child suffering from Kwashiorkor disease is shown in Fig. 3.

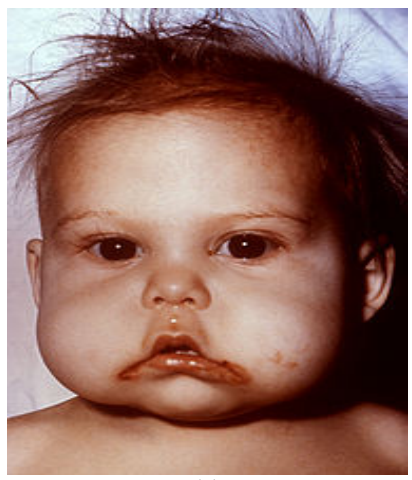

(a)

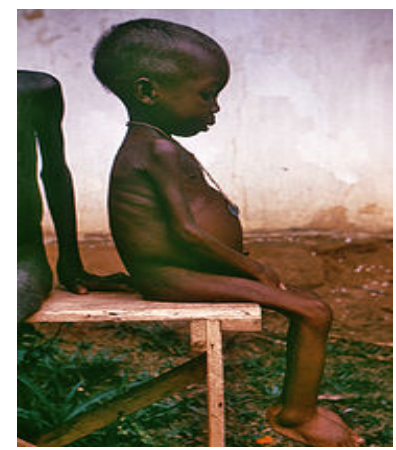

(b)

Fig. 3: Picture of children with kwashiorkor (a) Significant hair thining and edema and (b) Significant weight loss, fatigue and pot-belly

Early symptoms of kwashiorkor disease include: Fatigue, irritability and lethargy. As protein deprivation continues, growth failure, loss of muscle mass, swelling edema and decreased immunity occur. Other conditions include: Edema of the legs and feet, a pot-belly, light colored-thin hair, skin depigmentation, shiny skin, dermatitis, loss of teeth and enlarged liver (Cilinberto et al., 2005). Protein function in the body is to keep the blood from leaking out of the blood stream into the body tissues and cavities. When blood proteins are very low, serum seeps into the soft tissues and abdominal cavities causing defuse body swelling or edema and abdominal bloating or ascites. Aside from the direct effect of the disease, there are some secondary effects including: Lowered resistance to infection and the infection in turn reduces the capacity of the child to be nourished and enhances the malnourished condition. Kwashiorkor typically occurs at about age one after infants are weaned from breast milk to a protein deficient diet of starchy gruels or sugar water, but it can develope at any time during the formative years (WHO, 2002b; Krawinkel, 2003) Kwashiorkor patients mortality in poor countries is 18 - 
$30 \%$ (WHO, 2002b). Mortality rate of children 1-4 years of age in countries where Kwashiorkor is rare is only $1.0-3.8$ per 1000 population where mortality in countries where kwashiorkor is prevalent ranges from 12-60 per 1000 for the same age group (Badaloo et al., 2006; Pirie, 1975a). The global geographical distribution of kwashiorkor is show in Fig. 4. The areas of prevalence of this disease coincide with known areas of low malnutrition shown in Fig. 2.

Marasmus is a severe general malnutrition syndrome of both calorie and protein. It affects infants age 6-18 months old as a result of breast feeding failure or a debilitating condition such as diarrhea. Figure 5 shows a picture of a child with marasmus. The child looks emaciated and the body may be reduced to less than $80 \%$ of normal weight for that height. The malnutrition leads to extensive tissue and muscle wasting as well as variable edema, dry skin, loose skin folds hanging over the glutei and axcille, vomiting, lethargy and impaired immunity. The afflicted child becomes fretful, irritable and voraciously hungry (Cilinberto et al., 2005).

Protein malnutrition in adults is not easy to detect as in children and yet there may be far reaching effects including the prospect of permanent damage to organs in those adults who had a protein malnutrition experience when young which would influence the later habits and activities (WHO, 2002b).

Leaf protein: The amount of several essential amino acids in leaf protein has been seen to compare very well with those in animal proteins as shown in Table 3. Alfalfa has been shown to be a good supplement to low protein and low lysine diets in children and has shown better results than skimmed milk powder (Kinsella, 1970). Studies indicated that pigs fed on diets containing $4.9 \%$ supplementary protein as leaf protein concentrate required $10 \%$ less feed than pigs whose diet was supplemented with the same amounts of fish meal protein (Pirie, 1975a). Studies on rats showed amaranth to be an excellent protein supplement (Oke and Umph, 1970).

Parrish et al. (1974) found that most leaf protein have a biological value above 70. Kinsella (1970) reported a maximum biological value of 83 for leaf protein (Table 4) which compares well with soybean, sunflower seed and cotton seed meals. The true digestibility of leaf protein has been shown to vary between 80 and 90 which compares very well with high quality animal and vegetable proteins (Pirie, 1975a).

Microbial degradation and development of rancidity are the major problems encountered with the storage of leaf protein (Kinsella, 1970). The protein cake at $\mathrm{pH} 4.00$ (produced from acid precipitation) has the keeping qualities of cheese. A standard storage technique was developed by Morrison and Pirie (1961) in which protein cakes were put into moulds and dried to $30-40 \%$ dry matter and the blocks were wrapped in polythene plastic film and stored at $-10^{\circ} \mathrm{C}$. Storage for a few weeks did not change the flavor or physical properties of the protein, but prolonged storage caused the flavor to be leafy and the texture to be gritty. These changes could be counteracted by washing the protein in boiling water. Washing would also remove any toxins.

Factors affecting leaf protein content and quality: Selection of crops in conventional agriculture has been based on high dry matter production. However, the ratio of protein to dry matter is not constant due to the wide differences in the activities of metabolic systems of different species, which bring large variations in protein yield as shown in Fig. 6 (Kinsella, 1970).

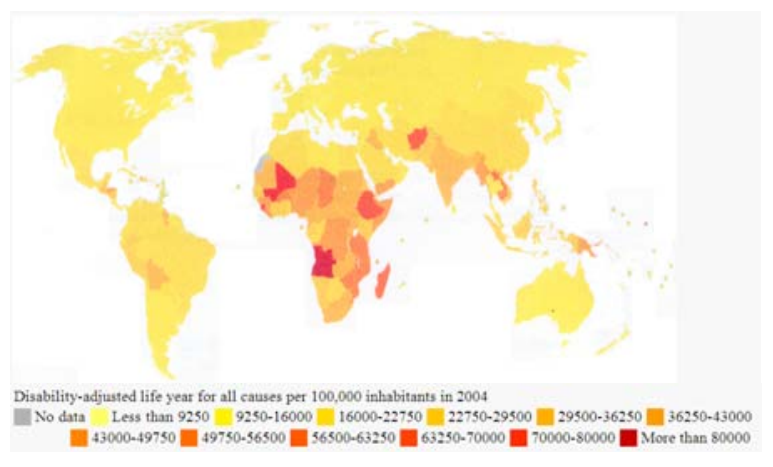

Fig. 4: Global geographical distribution of kwashiorkor

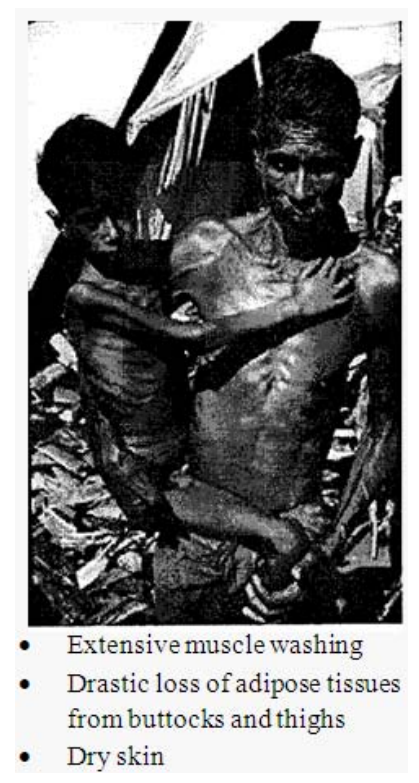

Fig. 5: Picture of a child with marasmus 
Am. J. Applied Sci., 7 (3): 331-342, 2010

Table 3: Essential amino acid composition of protein from leaf protein, vegetable meals, meats and eggs (WHO, 2007)

\begin{tabular}{|c|c|c|c|c|c|c|c|}
\hline \multirow{2}{*}{$\begin{array}{l}\text { Protein } \\
\text { source }\end{array}$} & \multicolumn{7}{|c|}{ Amino acid } \\
\hline & Lys & Phe & Met & Thr & Iso & Val & Tyr \\
\hline$\overline{\text { Alfalfa leaf }}$ & 6.3 & 6.0 & 2.1 & 5.2 & 9.8 & 6.3 & 1.6 \\
\hline Soybean meal & 6.4 & 4.8 & 0.6 & 3.7 & 3.5 & 5.0 & 1.2 \\
\hline Arachis meal & 3.1 & 5.4 & 1.1 & 3.4 & 4.0 & 4.7 & 1.3 \\
\hline Cotton seed meal & 4.9 & 5.4 & 1.5 & 3.7 & 3.3 & 4.2 & 6.3 \\
\hline Wheat glutenin & 0.8 & 6.4 & 1.5 & 4.1 & 3.7 & 4.2 & 0.7 \\
\hline Mixed grass & 4.8 & 5.8 & 2.3 & 4.7 & 5.7 & 6.8 & 2.1 \\
\hline Maize endosperm & 3.6 & 4.5 & 2.1 & 3.7 & 10.5 & 5.7 & 0.3 \\
\hline Whole hen egg & 7.2 & 6.3 & 4.1 & 4.3 & 4.1 & 4.0 & 1.5 \\
\hline Hen egg albumin & 6.3 & 7.2 & 4.4 & 4.5 & 7.4 & 7.5 & 1.3 \\
\hline Meat, poultry and fish & 8.1 & 4.9 & 3.3 & 4.6 & 7.7 & 5.8 & 1.3 \\
\hline
\end{tabular}

Lys: Lysine, Phe: Phenylalamine, Met: Methionine, Thr: Threonine, Iso: Isoleueine, Val: Laline, Tyr: Tyrosine

Table 4: Estimated biological value of various food proteins (Kinsella, 1970)

\begin{tabular}{ll}
\hline Product & Biological value \\
\hline Whole egg & 97 \\
Egg white & 87 \\
Lactalbumin & 84 \\
Milk & 83 \\
Casein & 76 \\
Beef & 75 \\
Leaf protein concentrate & 83 \\
Soybean & 65 \\
Cotton seed meal & 64 \\
\hline
\end{tabular}

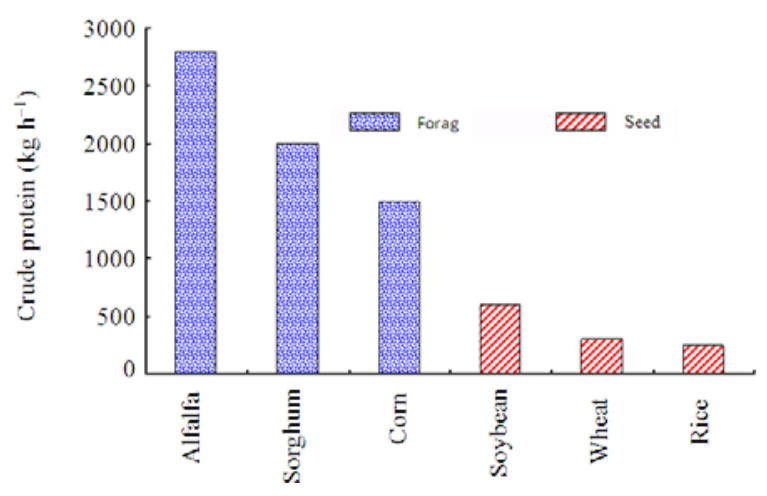

Fig. 6: Protein yield of various plants (WHO, 2007)

Also, high dry matter yields can be produced by crops like sugar cane and maize despite of their low protein content. Furthermore, rapid growth ensures a succulent plant comparatively free from secondary thickening and lignifications, so that cells may be readily ruptured and protein be easily released. Large yields are obtained from species that regrow very well over a long growth period (Crook, 1946; Betschart and Kinsella, 1973). With new machinery, extraction of protein from different plant species can be performed easily. It is now possible to extract $55-75 \%$ of crop nitrogen as protein from most plant species (Crook, 1946; Pirie, 1971).

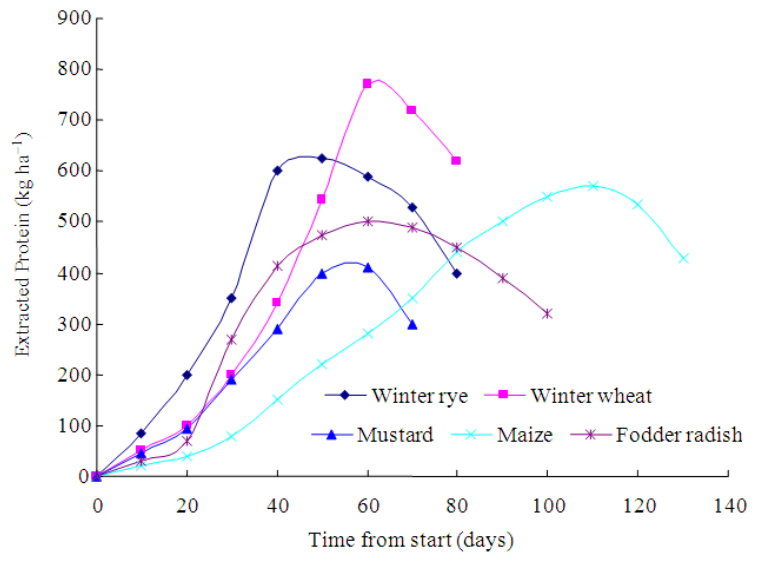

Fig. 7: Change in protein yield with age for various plants

All nutrients known to affect plant growth may influence its protein content and some of them will also alter the extraction rate by their effect on the juice to fiber ratio. Considerable lowering of protein yields were shown to be due to sulphur, phosphorus, potassium and magnesium deficiencies (Kinsella, 1970). However, the dominating element is nitrogen which promotes abundant succulent growth. Protein yields respond to heavy dressing of nitrogen. Nitrogen, also, improves the extraction rate by promoting luxurious plant growth. Finding the correct time to apply nitrogen is just as important as finding the optimum dressing (Pirie, 1971).

High protein yield is obtained by harvesting just before the end of the vegetative growth and beginning of the floral period. A few crops (as in case of fodder) continue to grow after the floral period, in which case the optimum age is extended over a longer period. Others wither (as in case of maize) after the floral period, in which case the optimum age is slowly reached after the floral period. The fall in yield after the optimum age makes harvest timing extremely critical for many crops. The rapid fall in yield is caused by the 
sudden cessation of protein synthesis while proteolysis continues resulting in a decline in protein extraction rate (Pirie, 1975b). Figure 7 shows the change in protein yield with age for various plants.

\section{MATERIALS AND METHODS}

Test plants: Six plants were tested in this study: Amaranth, cowpea, sugar been, pumpkin, sweet potato and cabbage.

Amaranth: The amatanth (Amaranthus hypocomdriacus) is a member of the botanical family amarantaceae. It is universally distributed and grows all over the world. It is a prolific plant with a good regrowth ability, thus allowing several cuts to be made through its vegetative period. The leaf color varies from purple to purplish green to full green. The plan does well in poor soil and under very adverse conditions. The plant yield is about $1600 \mathrm{Kg}$ fresh green leaves/ha. Most species including wild ones are eaten. The leaves are harvested as green vegetables and the white colored seeds are milled and incorporated with wheat flour and used to make bread.

Cowpea: The cowpea (Vigna unquilata) belongs to the botanical family leguminosae. It is most abundant in the north temperate regions of the world. The plant gives good silage, hay and pasture and is also a green manure and cover crop. Cowpeas climb using their tendrils for support. Leaves are alternate, compound and the fruit is a typical legume. Pollination is entomophilies (insectpollination) and the seed is non endospermic. The plant responds very well to fertilizer application and does not grow fast under very hot conditions. The rows must be cultivated until the vines overlap. The leaves are used as a special delicacy in many African countries including Zambia, Zimbabwe, Zaire and Nigeria where they are cooked fresh together with immature pods or may be dried and conserved for later use.

Sugar bean: The sugar bean (Phaseolus vulgaris), which is synonymously called kidney bean, belongs to the botanical family leguminosae. It is universally distributed all over the world. The beans are mainly grown both for the ripened seed and immature pods uses. The beans require a cool to warm frost-free climate and the plants may drop their blossoms or pods during excessively hot weather. The crop may be grown in soils ranging from sand to clay and peat. High moisture content and high nitrogen delay maturity. The beans are least responsive to fertilizer and application rate should be based on known requirement of the soil.
The leaves are not popular in most developing countries because they are hairy and not smooth. They are either eaten fresh or processes as in cowpea in several African countries.

Pumpkin: The pumpkin (Curcubita pepo) belongs to botanical family curcubitaceae. It is a very rapid growing plant and contains abundance of sap in the stems and other tissues. It has alternate, simple, broad and often deeply lobed palmate nerved and sometimes even compound. The tendrils are very sensitive and show all the phenomena of tendril climbing. The flower is an inflorescence, solitary, yellow in color and usually tubular. The fruit is among the largest known fruits in the world. A single pumpkin can weigh up to $45 \mathrm{~kg}$. The seed is non endospermic and is often flattened. Pumpkins are summer or warm weather crops and grow from direct seeding as they are very difficult to transplant. A light fertile soil that warms up quickly is desired especially for early maturing varieties. Pumpkin must be well supplied with organic matter and adequate moisture.

Sweet potato: The sweet potato (Ipomoea batatas) belongs to the botanical family convulvulaceae. It is a common plant in many parts of the world. It is a short day plant with a photoperiod of $11 \mathrm{~h}$. Less flowering occurs at $12 \mathrm{~h}$ day light and none at $15 \mathrm{~h}$ day light. Also, no flowering occurs above $30^{\circ} \mathrm{N}$ or below $30^{\circ} \mathrm{S}$ of the equator. The plant is propagated by stem cutting of $30-50 \mathrm{~cm}$ long taken from a specially grown mature plant. The bottom leaves are removed and the lower half of the cutting is inserted in the soil at an angle. Planting is on high ridges $(45 \mathrm{~cm}$ high and $90-120 \mathrm{~cm}$ wide) with cutting placed $30 \mathrm{~cm}$ a part. The plant responds well to organic manure. Too much nitrogen encourages vine growth which is desirable if the plant is grown for leaf harvest at the expense of tubers. Traditionally the leaves are eaten when young as they are most nutritious at this stage. They are a popular human delicacy in many African countries including Zimbabwe, Zambia and Nigeria where they are heat processed fresh.

Cabbage: The cabbage (Brassica olerocea) is the most common member of the cruciferous family. It has gained popularity in many developing countries in recent years. It is a hard vegetable that grows well in fertile soil. Ample moisture in the soil is required during the growing season. Cabbage is propagated by transplanting. Seedlings should be spaced $30-40 \mathrm{~cm}$ apart in all directions. Seeds can be sown in door $0.5-1 \mathrm{~cm}$ deep and must be kept moist. Since it is already 
consumed at a wide scale universally, it was used as a control in this study.

Plot preparation: A $12 \times 12 \mathrm{~m}$ test plot was ploughed using a rototiller. Four strips $(10 \mathrm{~m}$ length $\times 1 \mathrm{~m}$ width $)$ were prepared, 4 for sowing amaranth, cowpea, sugar been and one for transplanting cabbage seedlings. Two strips were made into ridges $(10 \mathrm{~m}$ length $\times 2 \mathrm{~m}$ width $\times 0.4 \mathrm{~m}$ height) for sweet potato propagation and sowing pumpkin. All seeds (seedlings or cuttings) were top dressed with urea fertilizer after sowing/planting at the rates recommended for each plant. The strips were shower irrigated.

Sowing: All plants were sown (planted or transplanted) on June 5 th at a small commercial vegetable farm. The seed rates for amaranth, cowpea, sugar bean, pumpkin were 2, 45, 60 and $20 \mathrm{Kg} \mathrm{ha}^{-1}$, respectively. The cowpea and sugar bean seeds were given a warm water treatment and then dressed with thiram to control fungal disease and dieldrin to control maggots. Also, pumpkin seeds were dressed with diedrim to control cutworm the amaranth, cowpea and sugar bean seeds were sown in rows $(10 \mathrm{~cm}$ a part within the row and $30 \mathrm{~cm}$ between rows). The pumpkin seeds were also sown in rows ( $20 \mathrm{~cm}$ a part within the row and $180 \mathrm{~cm}$ between rows). The amaranth, cowpea, sugar bean and pumpkin plants emerged after 8, 7, 6 and 12 days, respectively. Cuttings of sweet potato were propagated in rows $(30 \mathrm{~cm}$ a part within the row and $180 \mathrm{~cm}$ between rows). The shoots appeared from the buds after 12 days. cabbage seeds were sown in early May in a greenhouse and the seedlings were transplanted on June 5 th in rows $(30 \mathrm{~cm}$ a part within the row and $45 \mathrm{~cm}$ between rows). All plants showed quit good stand.

Harvesting: All plants were harvested on August 15 (after a growth period of 70 days) when they were at the blooming stage. Five kilograms of each plant species were collected and stored in a freezer at $-10^{\circ} \mathrm{C}$ (to prevent microbial spoilage and loss of B-carotene) till needed for protein analysis.

Protein extraction: The laboratory extraction procedure used in the study (Fig. 8) included: Moisture content and $\mathrm{pH}$ adjustment, pulping, filtering, cake pressing and coagulation of juice.

Protein extractability is closely related to leaf moisture content and $\mathrm{pH}$. A moisture content greater than $95 \%$ and a $\mathrm{pH}$ greater than 7.5 are recommended (Kinsella, 1970; Crook, 1946; Betschart and Kinsella, 1973). These conditions ensure softening of the cell wall and easy flow of leaf slurry.

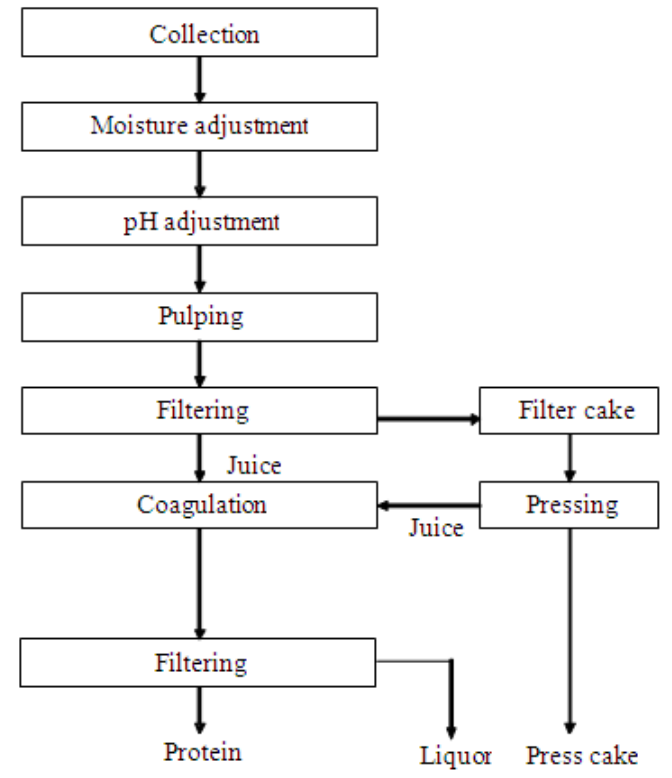

Fig. 8: Protein extraction procedure

Hundred grams of leaves were weighed using a digital balance (Mettler Scientific Balance AE 200S, Mettler Instruments, AG, Greifensee, Switzerland) and put in a 1 L blender (Waring Laboratories, Cat. No. 14-509-18, Fisher scientific, Montreal, Quebec, Canada). The blender has 6-blade stainless steel cutter/shredder. About $70 \mathrm{~mL}$ of $0.1 \mathrm{~N}$ Sodium Hydroxide and $170 \mathrm{~mL}$ of distilled water were added to the leaves. These would bring the moisture content and $\mathrm{pH}$ to $97 \%$ and 8.5 , respectively. The $\mathrm{pH}$ was measured using a digital $\mathrm{pH}$ meter (Philips PW9409, Fisher Scientific, Montreal, Quebec, Canada) and the moisture content was measured using the oven drying method described by the APHA (1988). A convection oven (Isotempoven, Model No. 655F, Fisher Scientific, Montreal, Quebec, Canada) was used and the samples were dried for $24 \mathrm{~h}$ at a temperature of $105^{\circ} \mathrm{C}$.

The mixture was blended for $30 \mathrm{sec}$ at low speed to shred the leaves and then for four 1 min periods at high speed for pulping. Any leaf pulp found sticking onto the blender wall was pushed down between the pulping periods.

A vacuum filtration system consisting of a funnel (Buchner 17J, Fisher Scientific, Montreal, Quebec, Canada), a flak and a vacuum pump (ED50 Speedivac, Edward High Vacuum Ltd, London, England) was used. A filter paper (Whatman No. 40, Fisher Scientific, Montreal, Quebec, Canada) was placed in the funnel. The pulp was poured from the blender into the funnel and the vacuum pump was stated. The pulp was filtered for $20 \mathrm{~min}$. 
Am. J. Applied Sci., 7 (3): 331-342, 2010

A specially constructed press was used for pressing the remaining juice out of the cake. It was manually adjusted press with a broad base strainer and $1 \mathrm{~mm}$ diameter sieve. Two filter papers (Whatman No. 40, Fisher Scientific, Montreal, Quebec, Canada) were placed in the strainer and the cake was placed above the filter papers. The cake was pressed at high temperature $\left(80^{\circ} \mathrm{C}\right)$ till all the juice stopped dripping. The process was completed in $10 \mathrm{~min}$.

The juices from the filtration and pressing processes were combined together. The mixture was then acidified to a $\mathrm{pH}$ of 3.5 by adding drops of $1 \mathrm{~N} \mathrm{HCl}$. The acidified juice was heated till the protein curd appeared firm and the whole mass floated above the liquor. The protein curd/liquor was filtered using the filtration system. The end product was clear a liquor in the flask and a firm protein cake in the funnel. The cake was washed and dried in an oven (Isotempoven, Model No. 655F, Fisher Scientific, Montreal, Quebec, Canada) at a low temperature $\left(40^{\circ} \mathrm{C}\right)$ to a moisture content of $10 \%$.

\section{RESULTS}

The extractable protein contents in the leaves of the six tested plants are shown in Table 5. Out of the six plants tested, pumpkin leaves recorded the highest protein yield $(11.75 \%)$. These leaves are in most cases eaten with peanut butter in most African countries and could prove to be a very reliable source of vegetable protein. Pumpkins are easy to crow and do not require the tender care as in most commercial vegetables. Pumpkin has a very good regrowth ability that allows several cuttings to be made, thereby increasing leaf protein yield per hectare.

The Amaranth was second in yield (10.5\%). The protein from amaranth was very smooth and less fibrous. This high protein content in amaranth agrees with the findings of Oke and Umoh (1970). Amaranth has a very good regrowth ability that allows several cuttings to be made, thereby increasing leaf protein yield per hectare.

The sugar bean leaves had the lowest protein yield $(3.45 \%)$, despite the high protein content in their (!4.45\%). The extraction process proved very difficult with sugar bean leaves and the protein extracted was not smooth, probably due to advanced maturity. When the leaves were mixed with immature pods (50:50 by weight), the protein content increased from $3.45-8.85 \%$ (by $157 \%$ ). The low protein yield in sugar bean leaves agrees with the general observation that extractability of protein from mature leaves is low (Kinsella, 1970; Staman, 1970; Morrison and Pirie, 1961; Crook, 1946; Betschart and Kinsella, 1973; Pirie, 1971).
Table 5: Measured leaf protein content (dry basis) for various plants

\begin{tabular}{lc}
\hline Plant & Protein content (\%) \\
\hline Pumpkin & 11.75 \\
Amaranth & 10.70 \\
Sugar been (with pods) & 8.85 \\
Sweet potato & 7.85 \\
Cowpea & 6.95 \\
Cabbage & 5.60 \\
Sugar been & 3.45 \\
\hline
\end{tabular}

The protein contents in the leaves of sweet potato, cowpea and cabbage were 7.85, 6.95 and 5.60\%, respectively.

\section{DISCUSSION}

The best protein yield can be obtained from leaves initially in good conditions. Clean cutting (without bruising) will ensure that the leaves do not deteriorate within a few hours when kept in cool place (Staman, 1970; Morrison and Pirie, 1961). Freezing leaves can improve protein extractability by as much as $30 \%$ (Kinsella, 1970).

The protein in the leaf cells was separated from the fiber by dissolving the protein in the cell sap and filtering off the sap. Since protein dissolution is strongly affected by the $\mathrm{pH}$ and moisture content, the moisture content was raised to $97 \%$ and the $\mathrm{p} \mathrm{H}$ was raised to 8.6. Base addition increased the protein solubility and facilitated cell sap liberation. At higher $\mathrm{pH}$, the cell wall swell freeing more pectase which further weaken the wall, allowing the cellulose and polysaccharides in the cell wall to soften and imbibe more water (Morrison and Pirie, 1961). Other advantages of the alkaline condition include: (a) it counteracts the acidic condition resulting from the rapture of acidic vacuoles during pulping which could denature the protein, making it unavailable for extraction (Kinsella, 1970) and (b) it results in increased recoveries of the nutritious xanthophylls and carotene (Parrish et al., 1974).

The pulping stage is the most critical in determining the extractability of leaf protein. It must be done quickly otherwise the protein will stick to the fibers and becomes difficult to extract (Parrish et al., 1974). With insufficient pulping, most of the juice in the leaf material would not be removed during the filtration and pressing of pulped material. Under pulping resulted in a coarse and fibrous cake with a leafy smell. Over pulping resulted the blockage of filter paper and thus, a failure to extract most of the juice from the pulped material and hence less protein yield. During the pressing process, when the leave were very slimy, little juice was obtained even at high pressure. 
Protein coagulation can be achieved by heat, acid or solvent precipitation. Heat $\left(80^{\circ} \mathrm{C}\right)$ coagulation was used in this study because steam injection lends itself to large scale operation, can result in $10-15 \%$ increase in filtrate and the curd is more denser and easy to filter (Morrison and Pirie, 1961). During coagulation, the $\mathrm{pH}$ must be kept under 6 (3-4 is optimum) or the texture of the curd will be slimy. The curd should be washed to improve its texture and remove the nonprotein and non-lipid constituents as well as the poisonous material, thereby improving its biological quality of the protein.

Protein cake kept at $4-10^{\circ} \mathrm{C}$ maintained its color, texture and aroma for at least 6 days. After 15 days, it appeared rather rough and gritty and the green color became much lighter. It, also, became hard like ginger biscuits but did not crack. Thus, in a case where this protein is to be fed in concentrate form, it is better to feed it to animals or add to human food within 2-5 days.

This study showed that pumpkin and amaranth appear to have the potential for use as plant protein sources for animal and human consumption. Their protein contents are within the ranges reported for several forages as shown in Table 6. However, no extensive studies have been made on their usage as possible leaf protein sources for human. Table 7 shows the composition of the leaf protein obtained from these two plants. Leaf protein can also provide the amide and essential amino acids (tyrosine, trtptophane, cysteine, methionine, arginine, histidine, lissine, glycine, proline, alanine, valine, leucine, isoleucine, norleucine and phanylalanine) (Lugg and Weller, 1944; Byers, 1961).

Table 6: Protein content of selected forages (Savoie, 1995)

\begin{tabular}{lc}
\hline Plant & Protein $(\%)$ \\
\hline Timothy grass & $7.0-11.2$ \\
Brome grass & $8.8-15.2$ \\
Orchard grass & $8.6-14.9$ \\
Reed canary grass & $8.4-13.6$ \\
Alfalfa & $14.8-18.1$ \\
Bird's foot & $13.6-18.8$ \\
Red clover & $17.1-17.5$ \\
White clover & $16.9-21.0$ \\
\hline
\end{tabular}

Table 7: Composition of pumpkin and amaranth leaf proteins

\begin{tabular}{lcc}
\hline Plant (\%) & Pumpkin & Amaranth \\
\hline True protein & 68 & 65 \\
Lipids & 26 & 20 \\
Starch & 3 & 10 \\
Fiber & 1 & 2 \\
Ash & 1 & 2 \\
Water soluble compounds & 1 & 1 \\
B-carotene $\left(\mathrm{mg} \mathrm{g}^{-1}\right)$ & 1 & 2 \\
\hline
\end{tabular}

Percentage-wise, the protein in the entire plants test in this study was less than in alfalfa. Alfalfa can give up to $4000 \mathrm{~kg}$ protein $\mathrm{ha}^{-1}$ (Parrish et al., 1974). Assuming that the amaranth produce $16000 \mathrm{~kg}$ fresh vegetable leaves $\mathrm{ha}^{-1}$ and at $10.7 \%$ protein content, $1712 \mathrm{~kg}$ protein ha ${ }^{-1}$ will be produced which is less than $50 \%$ of alfalfa protein. However, alfalfa is popular as an animal feed, not human food. Furthermore, the byproducts (liquor and fiber) of the extraction process have economic values. The liquor can be used as a growth medium for microorganisms. Its dry matter content is $2-4 \%$ and the nitrogen and carbohydrate in the dry matter are 30 and $40 \%$, respectively (Staman, 1970). The monosaccharides in the liquor are fructose and glucose. The fiber can be used as animal fodder. It has $10-20 \%$ moisture content, less lignification than fodder because the plants are harvested before maturity and less toxic substances because of washing (Pirie, 1971).

\section{CONCLUSION}

All the test plants compared favorably with cabbage and except for sugar bean they all had higher extractable protein content than cabbage. All the test plants are more widely grown and easier to grow. Proper use of the growing season can achieve high protein yield. Clean cutting will ensure that the leaves do not deteriorate within a few hours when kept in cool place and freezing leaves can improve protein extractability. The test plants should be given a trial as protein sources for human. The fact that their yield of protein per unit weight of leaves is low does not mean they should be ignored. Plant leaves have many advantages: (a) when consumed in adequate amounts, they can supplement protein especially in areas where the environment is very hostile to livestock keeping or where fish protein is lacking, (b) they have vitamins, minerals and contain 18 of the essential amino acids and (c) in plants like sugar bean and cowpea where the crop is mainly grown for seed harvest, at least two cuttings can be made before allowing the plants to grow to full maturity. However, further research is needed improve their potential as leaf protein sources. The optimum harvest age, the fertilizer requirements and the possibility of combining two or more plants together to improve protein content should be studied. The amino acid, minerals and vitamins profiles should also be determined.

\section{REFERENCES}

Altschul, A.M., 1965. Proteins: Their Chemistry and Politics. Basic Books, New York, pp: 337. 
APHA, 1988. Standard Methods for the Examination of Water and Wastewater. American Public health Association, DC., Washington, pp: 161.

Badaloo, A.V., T. Forrester, M. Reid and F. Jahoor, 2006. Lipid kinetic differences between children with kwashiorkor and those with marasmus. Am. J. Clin. Nut., 83: 1283-1283.

Betschart, A. and J.E. Kinsella, 1973. Extractability and solubility of leaf protein. J. Agric. Food Chem., 21: 60-65.

Bhatia, J. and F. Greer, 2008. Use of soy protein based formulas in infant feeding paediatrics. 121: 1062-1068.

Brocchieri, L. and S. Karlin, 2005. Protein length in eukaryotic and prokaryotic proteomes. Nucleic Acids Res., 33: 3390-3400.

Byers, M., 1961. Extraction of protein from the of some leaves growing in Ghana. J. Sci. Food Agric., 12: $20-30$.

CDCP, 2008. Nutrition for every one prevention. http://www.cdc.gov/nccdphp/dnpa/nutrition/nutriti on_for_everyone/basic/protein.htm

Chaing, Y.S., T.I. Gelfand, A.E. Kister and I.M. Gelfand, 2007. New classification of super secondary structures of sandwich-like protein uncovers strict patterns and strand assemblage. Proteins, 68: 915-921.

Cilinberto, H., M. Ciliberto, A. Briend, P. Ashorn and D. Bier et al., 2005. Antioxidant supplementation for prevention of kwashiorkor in Malawian children: Randomised, double blind, placebo controlled trial. Br. Med. J., 330: 1109-1114.

Crook, E.M., 1946. The extraction of nitrogenous materials from green leaves. Biochem. J., 40: 197-209.

FAO, 2008. Protein and the child. Report of the protein advisory group, world food programme, food and agriculture organization, United Nations, Rome, Italy.

Ferrianti, M.P. and A. Fiechter, 1983. Production and Feeding of Single Cell Protein. Applied Science Publications, London.

Furst, P. and P. Stehle, 2004. What are the essential elements needed for the determination of amino acids requirements in humans. J. Nut., 134: 1558S$1565 \mathrm{~S}$.

Gasperini, L. and C. Maguire, 2001. Targeting the Rural Poor: The Role of Education and Training. Sustainable Development, Food and Agriculture Organization of the United Nations. http://www.fao/sd/2002/kn0301a_en.htm

Imura, K. and A. Okada, 1998. Amino acid metabolism in podiatric patients. Nutrition, 14: 143-148.
JADA, 2003. Position of the American dietetic association and dieticians of Canada: Vegetarian diets. J. Am. Dietetic Assoc., 103: 748-765.

Kinsella, J.E., 1970. Evaluation of plant leaf protein as a source of food protein. Chem. Ind., 17: 550-554.

Krawinkel, M., 2003. Kwashiorkor is still not fully understood. WHO Bull., 81: 910-911.

Kuijer, O.C.H. and D.K. Wielenga, 1999. A Comparison of the Environmental Impact of Meat Alternatives and the Attractiveness of the Alternatives of the Consumers VROM. Products Policy 1999/35, The Hague, Netherlands.

Latharn, M.C., 1997. Human Nutrition in the Developing World. Food and Agricultural Organization of the United Nations. Rome, Italy, ISBN-10: $925103818 X$ pp: 522.

Lugg, J.W.H. and R.A. Weller, 1944. Large scale extraction of protein samples representative of the whole protein in the leaves of some plants: The Amide, Tyrosine, Tryptophan, Cystine (plus Cysteine) and Methionine Contents of the Preparations. Biochem. J., 38: 408-411.

McGilvery, R.W., 1979. Biochemistry: A Functional Approach. Blackwell Scientific Publishers, London.

Mendez, M.A., M.S. Anthony and L. Arab, 2002. Soybased formulae and infant growth and development: A review. J. Nutr., 132: 2127-2130.

Morrison, J.E. and N.W. Pirie, 1961. The large-scale production of protein from leaf extracts. J. Sci. Food Agric., 12: 1-5.

Oke, O.L. and I.B. Umph, 1970. Nutritive value of leaf protein. Nutr. Rep. Int., 10: 73-82.

Pariser, E.R., M.B. Wallerstein, C.J. Corkery and N.L. Brown, 1978. Fish Protein Concentrate: Panacea for Protein Malnutrition. ISBN-10: 0262160692, pp: 256.

Parrish, G.K., M. Kroger, J.C. Weaver and T. Furia, 1974. The prospects of leaf protein as a human foodand A close look at Alfalfa. CRC Crit. Rev. Food Technol., 5: 1-13.

Paulin, L., R.B. Corey and H.R. Branson, 1951. The structure of protein: Two hydrogen-bonded helical configurations of the polypeptide chain. Proc. Nat. Acad. Sci. USA., 37: 205-211.

Pirie, N.W. 1971. Leaf Protein: Its Agronomy, Preparation, Quality and use. International Biological Programme. London, ISBN-10: 0632083506, pp: 192.

Pirie, N.W., 1975a. Protein nutritional quality. Baroda J. Nutr., 2: 43-48.

Pirie, N.W., 1975b. Leaf protein: A beneficiary of tribulation. Nature, 253: 239-241. 
Reeds, P.J., 2000. Dispensable and indispensable amino acids for humans. J. Nutr., 130: 1835-1840.

Savoie, P., 1995. High value extracts from forages and straws. Proceeding of the Northeast Agricultural and Biological Engineering Conference, (NABEC'95), Saint-Foy, Quebec, pp: 95-18.

Sikka, K.C., R. Singh, D.P. Gupta and S.K. Duggal, 1979. Comparative nutritive value of Fish Protein Concentrate (FPC) from different species of fishes. J. Agric. Food Chem., 27: 946-949.

Staman, M.A., 1970. Alfalfa protein concentration for human and animal consumption. Agric. Eng., 51: 1120114 .

Tannenhaum, S.R. and D.I.C. Wang, 1975. Single Cell Protein2. The MIT Press, Boston, Massachusetts, pp: 707.

WHO, 2002a. Childhood Nutrition and Progress. In: Implementing the International Code of Marketing of Breast-Milk Substitutes, World Health Organization, Geneva, A55/14.
WHO, 2002b. Mortality and Burden of Disease Estimates for WHO Member States. World Health Organization.

http://www.who.int/entity/healthinfo/statistics/bod gbddeathdalyesti

WHO, 2007. Protein and Amino Acid Requirements in Human Nutrition. World Health Organization Press, Rome, Italy

WHO/UN, 2007. World Population Prospects: 2006 Revision Highlights. Department of Economic and Social Affairs, Population Division. United Nation, New York.

Williams, C., 1953. Kwashiorkor: A nutritional disease of children associated with a maize diet. Lancet, 226: 1151-1152.

Young, V.R., 1994. Adult amino acids requirements: The case for major revision in current recommendations. J. Nut., 124: 1517S-1521S. 